\title{
SMS and Web-Based e-Government Model Case Study: Citizens Complaints Management System at District of Gihosha -Burundi
}

\author{
Mugenzi Thierry*1, Tri Kuntoro Priyambodo $^{2}$ \\ ${ }^{1}$ Hope Africa University, Burundi \\ ${ }^{2}$ Department of Computer Science and Electronics, FMIPA UGM, Yogyakarta \\ e-mail: *1' mugenzithierry@yahoo.fr, ${ }^{2}$ mastri@ugm.ac.id
}

\begin{abstract}
Abstrak
E-Government pada dasarnya terdiri dari penggunaan teknologi komunikasi elektronik seperti internet, dalam meningkatkan dan memajukan akses warga terhadap pelayanan publik. Di sebagian besar negara-negara berkembang termasuk Burundi, warga menghadapi banyak kesulitan untuk mengakses pelayanan publik. Salah satu masalah yang diidentifikasi adalah rendahnya kualitas layanan dalam mengelola keluhan warga di tingkat Kabupaten. Penelitian ini mengusulkan sebuah model e-Government berbasis SMS dan web sebagai solusi untuk meningkatkan manajemen keluhan warga negara juga untuk meningkatkan pelayanan publik akses oleh warga. Dalam penelitian ini, studi kasus dari sistem manajemen keluhan di Kabupaten Gihosha telah digunakan sebagai referensi untuk membuktikan bahwa model eGovernment berbasis SMS dan web dapat meningkatkan akses pelayanan publik di Republik Burundi. Tujuan dari penelitian ini adalah pengembangan dari sistem berbasis SMS dan web yang akan meningkatkan proses dan pengelolaan keluhan warga di Kabupaten Gihosha. sistem ini dikembangkan menggunakan PHP sebagai front end, Apache sebagai web server, MySQL sebagai database dan Gammu sebagai SMS gateway.Hasil yang diperoleh setelah pengujian sistem menunjukkan bahwa semua fungsi dari sistem yang dikembangkan bekerja dengan benar. Dengan demikian, sistem manajemen pengaduan berbasis SMS dan web dikembangkan dianggap efektif.
\end{abstract}

Kata kunci-Warga negara, e-Government, pelayanan publik, pengelolaan pengaduan, SMS gateway

\begin{abstract}
E-Government basically comprises the use of electronic communications technologies such as the internet, in enhancing and advancing the citizens access to public services. In most developing countries including Burundi, citizens are facing many difficulties for accessing public services. One of the identified problems is the poor quality of service in managing citizens' complaints. This study proposes an SMS and web based e-Government Model as a solution. In this study, a case study of a complaint management system at district of Gihosha has been used as a reference to prove that SMS and web based e-Government Model can enhances the access of public services. The objective of this study is the development of an SMS and web-based system that can enhances the process and the management of citizens' complaints at district of Gihosha. The system has been developed using PHP as front end, Apache as web server, MySQL as database and Gammu as SMS gateway. The obtained results after testing the system shows that all the functionalities of the developed system worked properly. Thus, the SMS and web based complaint management system developed is considered to be effective.
\end{abstract}

Keywords-Citizen, e-Government, public services, complaints management, SMS gateway 


\section{INTRODUCTION}

$\mathrm{E}_{\mathrm{c}}^{-}$ Government is the conventional government services made available for citizens through electronic means such as telephone, digital television and internet connected computers and other devices. Internet is increasingly becoming the medium of delivering government services to citizens in an effective and cheaper way. The development of mobile technologies with the introduction of internet enabled mobile phones, PDA's, Wi Fi and wireless network to create a new channel to deliver government services to citizens.

SMS-based e-Government is more likely to increase e-Government usage than the current internet based e-Government. SMS-based e-Government could be the more appropriate channel to deliver e-Government services in developing countries. Since e-Government service is for every citizen, a leading-edge technology should not be adopted unless most citizens are ready to use it [1].

In republic of Burundi, the cost of accessing government services and even information is very high. It goes even higher if we add the cost of transportation on top of the unofficial service cost. The quality of service delivery is very poor especially in citizen complaint's management. Most of the time the persons in charge of answering the citizens' complaints take long time to reply and sometimes they can even ignore the citizens' complaints. The only one way citizens make complaints is by walking in and face to face meeting with the staff in charge. The concerned staff has to write down the citizens' complaints on a paper then constitute a file of citizens' complaints which would keep moving in different offices with a high risk of disappearing. Since there is no computerized system to manage how complaints are managed, it's difficult for the district administrators to make reports regarding the citizens' complaints.

The government recently has taken several measures by introducing e-Government services for ensuring easy access to government information and success. Despite the effort of the government of implementing e-Government, it is still at the initial state due to the lack of telecommunication infrastructure, only $5 \%$ of population use internet [2]. Burundi has one of the lowest score in e-Government $(6 \%)$. With this background, Burundi needs such a common media that is easy to use and more available to mass people. With $31 \%$ of mobile phone users [2], SMS based e-Government is more likely to be implemented easily in a country like Burundi.

As solution, a system based on SMS and web to manage citizens' complaints at district of Gihosha is proposed in this paper.

\section{RESEARCH METHODOLOGY}

The research methodoly comprises 2 phases; the first phase is the data collection which consists of collecting all relevant information to determine the user and system requirements; the second is the system design.

\section{1 Data collection}

Data collection has been done by two methods: literature study and interviews. Literature study has been carried out by studying various literatures related to this research topic such as scientific journals, research reports, magazines and books.

Interviews has been conducted by means of questioning people who have the capacity and required information related to this research. The administrator of district of Gihosha in republic of Burundi and the director of in charges of public services in the ministry of interior have been questioned.

IJCCS Vol. 11, No. 1, January 2017: $67-76$ 


\section{2 Requirements analysis}

Based on the conducted interviews, it can be concluded the functional requirements are as follows:

- The user should be able to access his account at any time.

- The application should be portable, it should run under different web-browsers

- The user Interface design should be simple, logical and useable by the user.

- There should be different user privilege roles.

- The application usability should be highly

The result of user requirements analysis is the determination of the business process of the proposed system. The business process is shown in Figure 1.

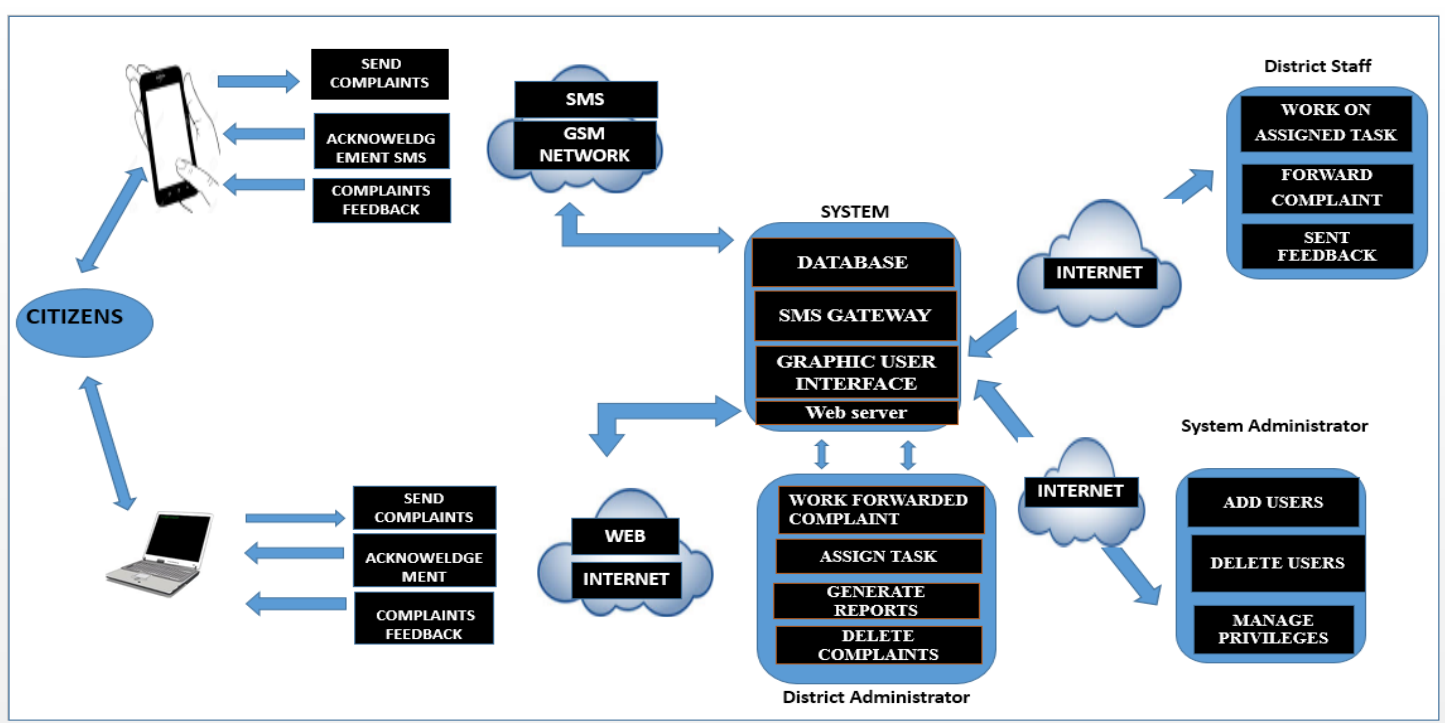

Figure 1 Business process of the proposed system

The involved actors and their actions are shown in Table 1.

Table 1 Business process involved actors

\begin{tabular}{|l|l|}
\hline Actors & Description \\
\hline System Administrator & $\begin{array}{l}\text { System administrator has the highest } \\
\text { privileges to manage master data in the } \\
\text { database i.e. citizen data, employee data and } \\
\text { complaint data. And he has the privilege also } \\
\text { to create or delete users. }\end{array}$ \\
\hline District Administrator & $\begin{array}{l}\text { District Administrator has the privileges to } \\
\text { Assign task to employee, work on forwarded } \\
\text { complaints by the staff and Generate various } \\
\text { report. }\end{array}$ \\
\hline District Staff(Employee) & $\begin{array}{l}\text { Employees only have access to manage and } \\
\text { solve the assigned task; they can forward the } \\
\text { assigned complaint to other employees or to } \\
\text { District Admin in case they need assistance. }\end{array}$ \\
\hline Citizens & $\begin{array}{l}\text { Citizens can make complaints online or via } \\
\text { SMS, process, View the complaint status and } \\
\text { receive the complaint feedback online or via } \\
\text { SMS. }\end{array}$ \\
\hline
\end{tabular}




\section{3 System Design}

System design is the process of defining the architecture, components, modules, interfaces, and data for a system to satisfy specified requirements [3]. The unified modeling language (UML) has been used as modeling language to provide the visualization of the system design.

\section{3.1 Architecture Design}

This stage consists of the determination of what is needed, how the citizen will interact with the proposed system and important events that will occur in the system environment. The output of this stage is the architecture of the proposed system. The system architecture is shown in Figure 2.

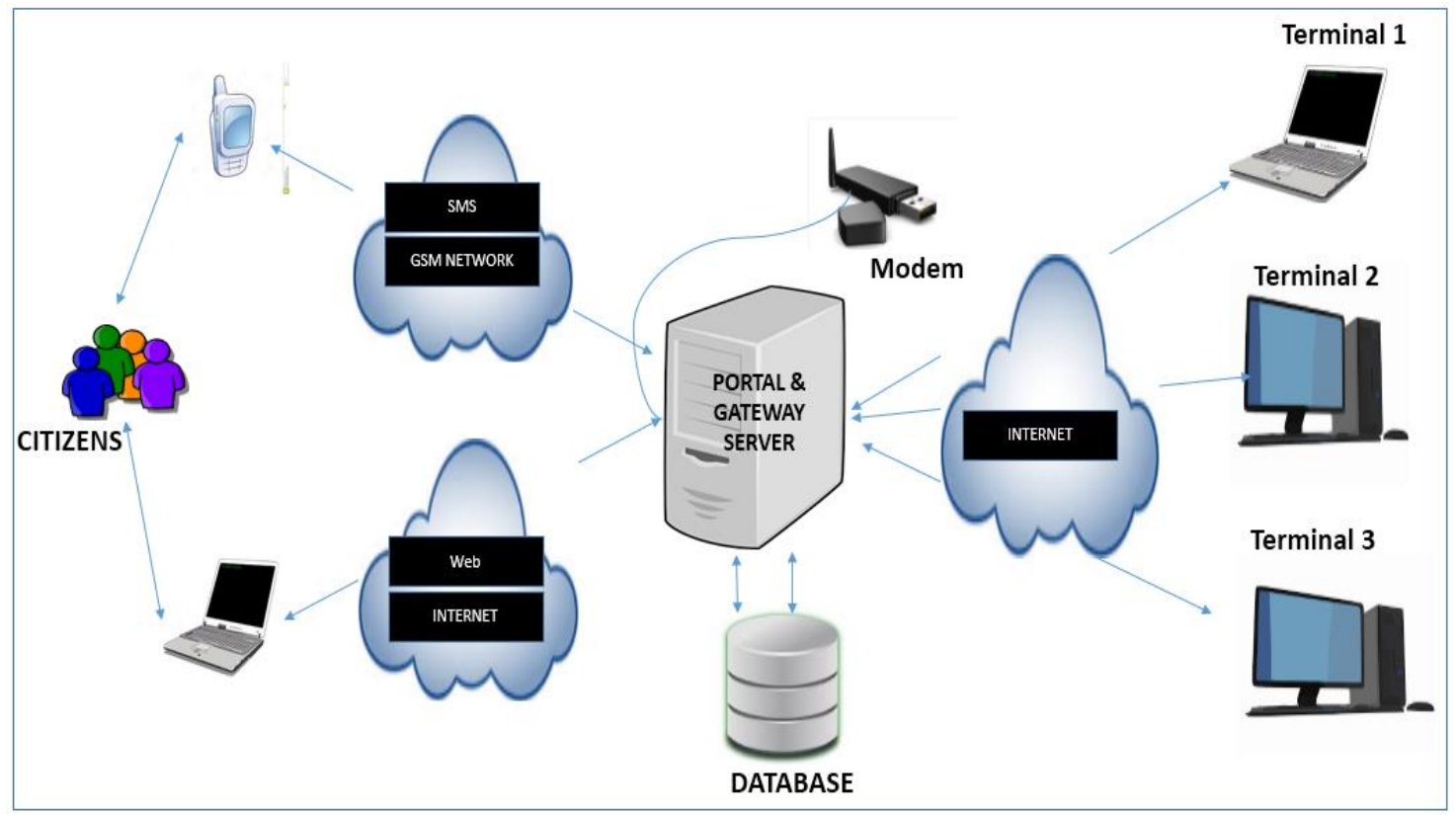

Figure 2 System Architecture

According to the architecture of the proposed system, citizens will interact with the system via internet or via SMS. citizens could access the system online through a web-browser. A modem will be used to connect the system to the GSM network then to allow to send and to receive SMS. The proposed system will be build using html, CSS, and PHP as programming language, MySQL database and Gammu as SMS gateway. The system will be hosted using Apache HTTP Server on a machine running Windows 7(32bit).

\section{3.2 User Interface Design}

User interface (UI) design focuses on anticipating what users might need to do and ensuring that the interface has elements that are easy to access, understand, and use to facilitate those actions [4] [5].The user interface design consist mainly in designing the forms used by users while using the system.

\section{3.3 Database design}

Database is used to store citizen's complaint and the answers to the complaints, the citizen's identification data and the transactions between citizens and district staff in charge of replying their complaints. Database design also describes the system architecture to be built. The database inputs are shown in Figure 3. 


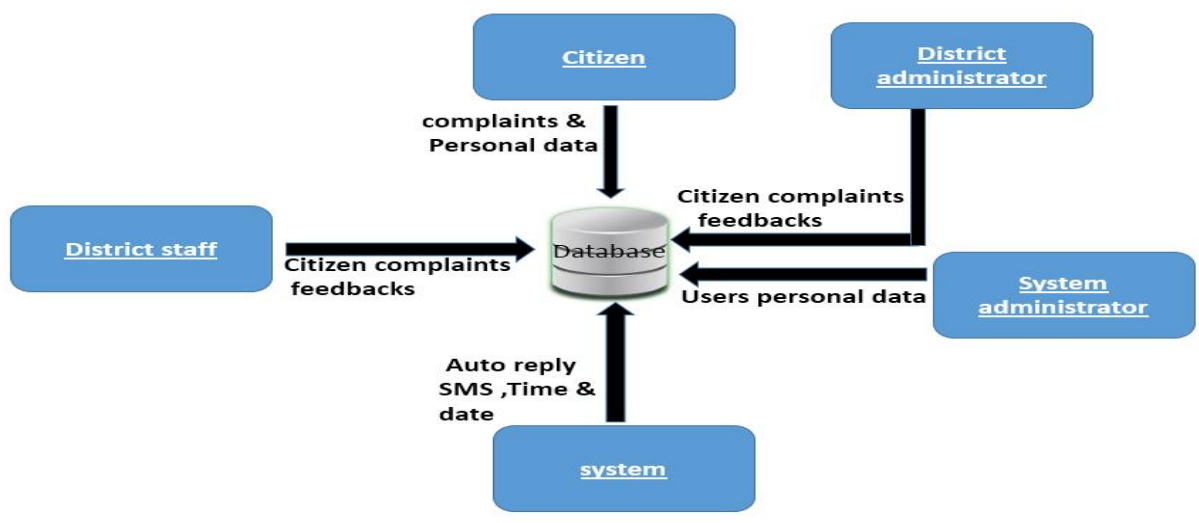

Figure 3 Database input

\section{3.4 Use case diagram}

A use case diagram at its simplest is a representation of a user's interaction with the system that shows the relationship between the user and the different use cases in which the user is involved. A use case diagram can identify the different types of users of a system and the different use cases and will often be accompanied by other types of diagrams as well [6].It contains four actors which are citizen, district staff, district administrator and system administrator and the functions performed by these actors. The use case diagram of the proposed system is shown Figure 4.

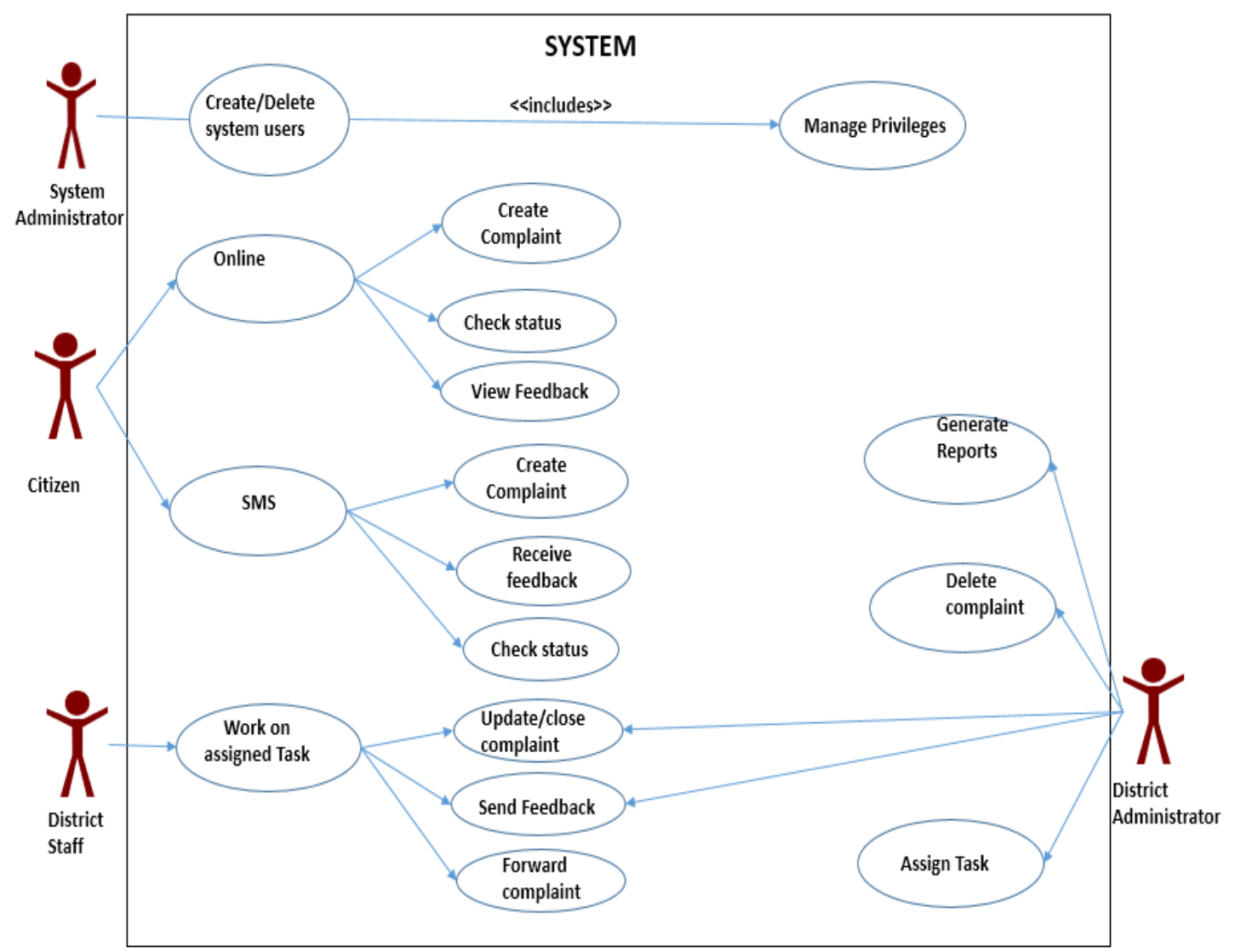

Figure 4 Use Case Diagram 


\subsubsection{Class Diagram}

The class diagram is a static diagram which represents the static view of an application.

Class diagram is not only used for visualizing, describing and documenting different aspects of a system but also for constructing executable code of the software application [7]. The class diagram of the proposed system is shown in Figure 5.

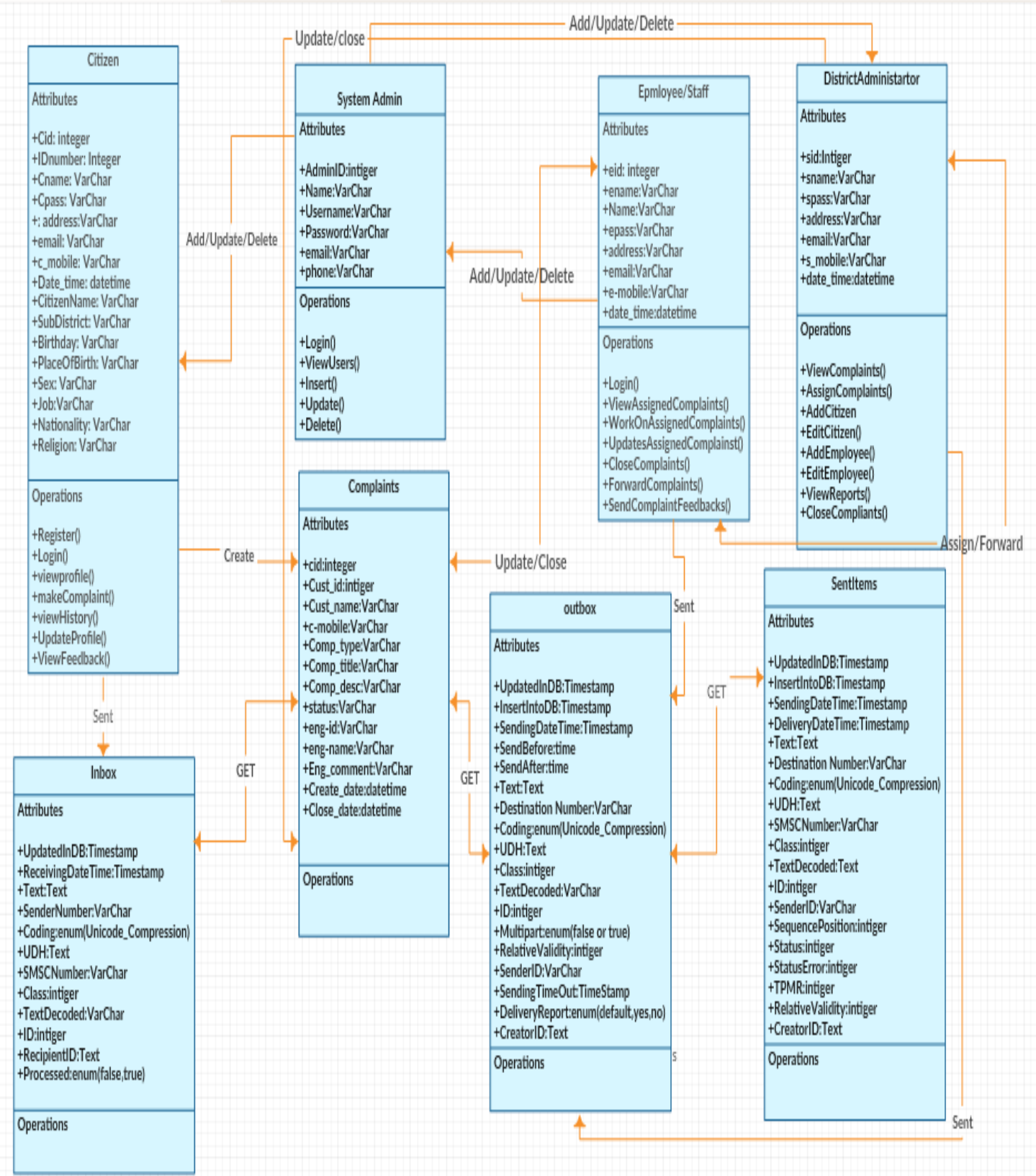

Figure 5 Class Diagram

\subsubsection{Activity Diagram}

Activity diagram is basically a flow chart to represent the flow form one activity to another activity. The activity can be described as an operation of the system . So the control flow is drawn from one operation to another [8]. Activity diagram of the proposed system is shown in Figure 6 and 7. 


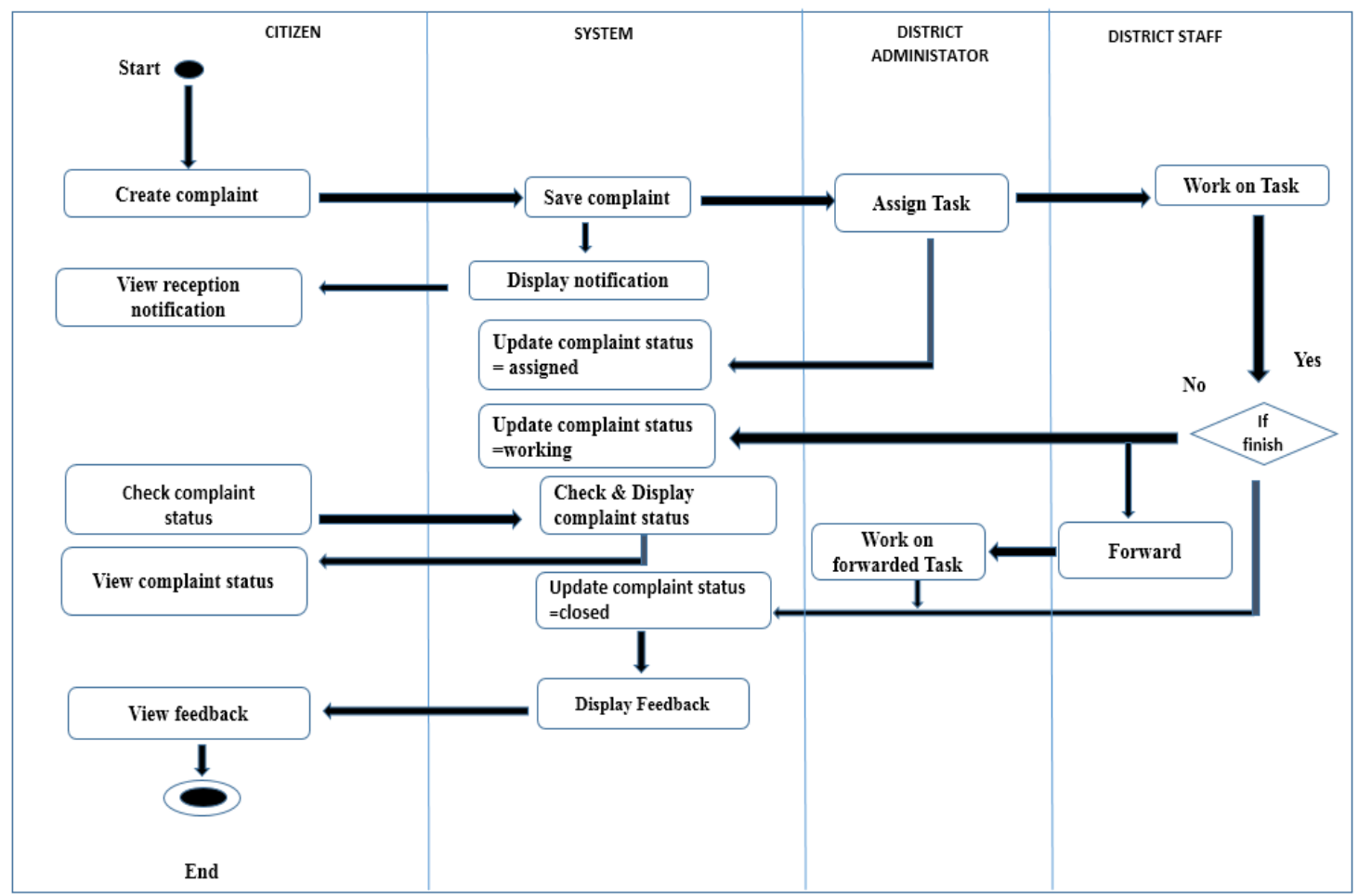

Figure 6 Activity diagram online complaint

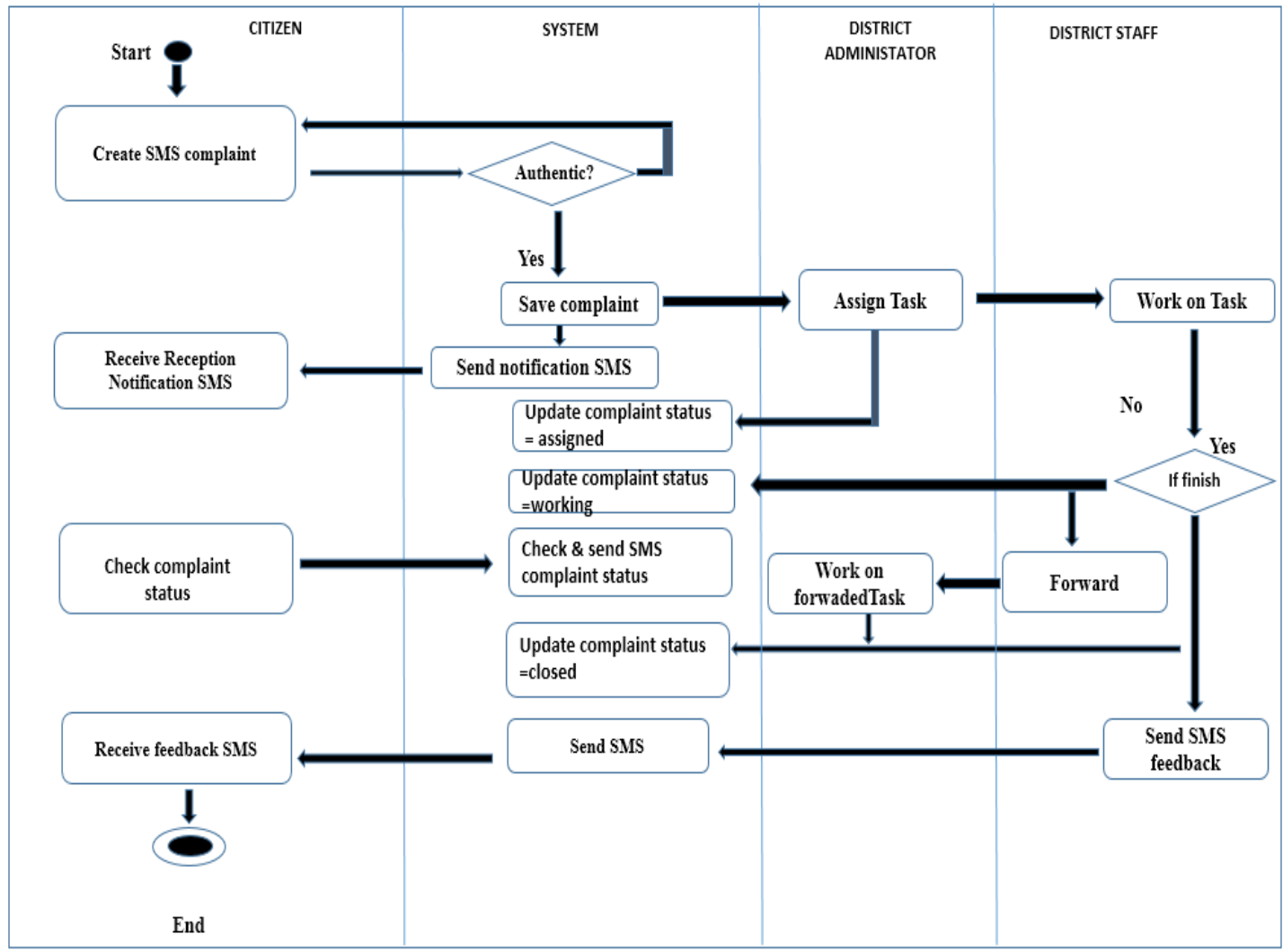

Figure 7 Activity diagram SMS complaint 


\subsection{Implementation}

As mentioned earlier in the System design, a web and SMS based complaint management prototype has been built to support this research. The proposed system has been developed using PHP as front end, Apache as web server, MySQL as database and Gammu as SMS gateway.

\section{RESULTS AND DISCUSSION}

The developed system has been tested, according to the scope of the study and the objective of this research which mainly focus on the functionality and usability of the developed prototype of the citizen's complaint management system based on web and SMS, only functionality, portability and usability test has been carried out. The functionality testing consists of testing all the links in web pages, database connection, forms used in the web pages for submitting or getting information from user. The result of functionality testing is shown in Table 2 .

Table 2 Result of system functionality testing

\begin{tabular}{|c|c|c|c|}
\hline Input/Event & Proses & Output & Result \\
\hline $\begin{array}{l}\text { Gammu SMS } \\
\text { gateway and GSM } \\
\text { modem connection }\end{array}$ & $\begin{array}{l}\text { Link:C:Igammulbin|gamm } \\
\text { urc }\end{array}$ & $\begin{array}{l}\text { Gammu \& GSM modem } \\
\text { connection establishement }\end{array}$ & success \\
\hline $\begin{array}{l}\text { Gammu SMS } \\
\text { gateway and Mysql } \\
\text { database }\end{array}$ & $\begin{array}{l}\text { Link:C:Igammulbinlsmsdr } \\
\text { c }\end{array}$ & $\begin{array}{l}\text { Gammu \& Mysql database } \\
\text { connection establishement }\end{array}$ & success \\
\hline $\begin{array}{l}\text { Database } \\
\text { connection }\end{array}$ & Link : config.php & $\begin{array}{l}\text { Connection to } \\
\text { complain_db }\end{array}$ & success \\
\hline Database testing & Link : functions.php & $\begin{array}{l}\text { queries are executed } \\
\text { correctly, data is retrieved } \\
\text { correctly and also updated } \\
\text { correctly }\end{array}$ & success \\
\hline $\begin{array}{l}\text { Accessibility to the } \\
\text { proposed system }\end{array}$ & http://localhost/cms2 & welcome page & success \\
\hline $\begin{array}{l}\text { Make complaint } \\
\text { via SMS }\end{array}$ & Link : functions.php & Complaint registered & success \\
\hline $\begin{array}{l}\text { Make complaint } \\
\text { online }\end{array}$ & Link: makeComplain.php & Make complaint form & success \\
\hline $\begin{array}{l}\text { Send feedback to } \\
\text { citizen }\end{array}$ & Link: autoreply.php & $\begin{array}{l}\text { Feedback SMS sent to } \\
\text { citizen }\end{array}$ & success \\
\hline
\end{tabular}

IJCCS Vol. 11, No. 1, January 2017 : $67-76$ 
The results obtained after the functionality testing of the built prototype showed that all the functionalities run properly therefore the built prototype meets the functional and user requirements. For usability testing of the built system, summative usability testing methods has been used [9] and the IBM computer system usability questionnaire has been used for the survey [10].After analyzing the survey results, the usability score of the built prototype is 81.9 $\%$ which means that the built system is highly usable. The summary of the usability testing result is shown in Figure 8.

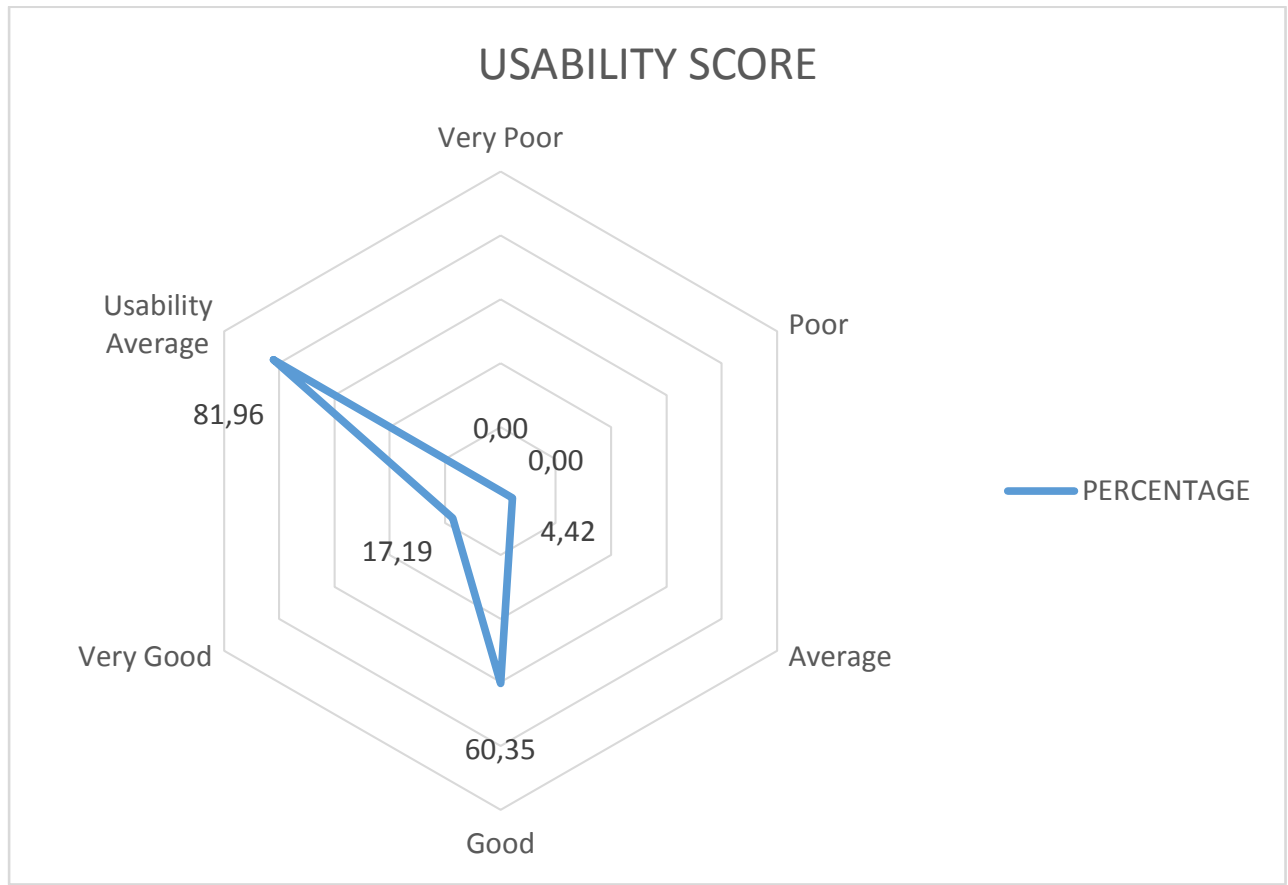

Figure 8 Usability Score

The portability testing has been carried out to check if the system can run under different environment. As the built system is a web based system, the system has been tested through different web browsers. The result showed that the system could run properly on Chrome, Firefox, Opera, Safari, and Internet explorer.

A web based application is said to meet the aspect of portability if it can be read on a variety of web browsers [11]. Based on the results obtained after the portability testing of the built system, it can be said that the built system fulfills the portability requirements.

\section{CONCLUSION}

Based on the result of the study that has been carried out, it can be concluded that:

1. The SMS and web based application for managing citizen's complaints at district Gihosha has been designed and built using html, CSS, and PHP as programming language, apache server, MySQL database and Gammu as SMS gateway.

2. The obtained result after the testing phase shows that all the functionalities of the built system run properly, the built prototype of system is portable and highly usable with a rate of usability of $81,9 \%$.

3. The proposed and built system's prototype is a combination of two e-Government models, SMS and web based e-government model and through this e-Government model the access to public services by the citizens of the district of Gihosha could be enhanced. 
4. Based on the result of the study that has been carried out, it can be concluded that the objective of this research has been achieved successfully with the best practices in designing and building a usable prototype of a SMS and web based application for managing and handling citizens' complaints at district of Gihosha in republic of Burundi.

\section{RECOMENDATION}

This paper covered only how citizens' complaints can be managed at district level; the author can give suggestions that for the future work:

1 . This system can be extended by adding functionalities so it can allow the full access to public services.

2. The testing of the system can be extended and include factors such as Performance and security.

\section{REFERENCE}

[1] Susanto, T.D. \& Goodwin, R.D., 2006, An SMS-based e-Government model. Proceedings of the Eighth International Conference on Enterprise Information Systems, 185-188.

[2] United Nations (UN) E-Government Survey, 2014, http://publicadministration.un.org/ egovkb/en-us/Reports/UN-E-Government-Survey-2014, accessed on $28^{\text {th }}$ April 2016.

[3] Dennis, A, Wixom B, Roth R., 2012, System Analysis and Design. Fifth Edition.

[4] Garrett's, J. J., 2011, The Elements of User Experience: User-Centered Design for the Web and Beyond (2nd Edition).

[5] Morville, P and Rosenfeld, L, 2006, Information Architecture for the World Wide Web: Designing Large-Scale Web Sites. ( $3^{\text {rd }}$ Edition).

[6] Gemino, A. and Parker, D., 2009, Use case diagrams in support of use case modeling: Deriving understanding from the picture", Journal of Database Management, 20(1), 1-24.

[7] Bell, D., 2004, An introduction to structure diagrams in UML 2, http://www.ibm.com/developerworks/rationa/library/content/rationalEdge/sep04/bell/acces sed on16th May 20016.

[8] UML activity diagram, 2014, http://www.tutorialspoint.com/uml/uml_ activity_diagram.htm, accessed on $13^{\text {th }}$ May 2016.

[9] Dumas, J.S. \& Redish, J.C., 1999, A practical guide to usability testing. Exeter: intellect.

[10] Lewis, J.R., 1995, IBM Computer Usability Satisfaction Questionnaires: Psychometric Evaluation and Instructions for Use. International Journal of Human-Computer Interaction $7(1), 57-78$

[11] Schach, S. R., 2008, Object-oriented software engineering, index. ISBN 978-0-07-3523330 